\title{
FEEDING PREFERENCE OF THE SEA URCHIN LYTECHINUS VARIEGATUS (LAMARCK, 1816) ON SEAWEEDS
}

\author{
Camilla Ferreira Souza, Aline Santos de Oliveira and Renato Crespo Pereira* \\ Universidade Federal Fluminense \\ Departamento de Biologia Marinha \\ (Caixa Postal 100644, 24001-970 Niterói, RJ, Brasil) \\ *Corresponding author: renato.pereira@pq.cnpq.br
}

\begin{abstract}
A B S T R A C T
Seaweeds exhibit different strategies to minimize the damage caused by herbivores and also to influence the feeding preference of these consumers. This study evaluated the feeding preference of the sea urchin Lytechinus variegatus through multiple-choice experiments using the seaweeds Caulerpa racemosa, Dictyota menstrualis, Osmundaria obtusiloba, Plocamium brasiliense, Sargassum sp., and Ulva sp. In order to verify the importance of morphological and chemical aspects on this feeding preference, two assay-types were carried out using live and powdered macroalgae, respectively. Two different methods were employed to analyze the results obtained: comparison between biomass losses versus autogenic changes, and inclusion of autogenic values in biomass loss through herbivory. In both experiments a clear differential consumption of certain species of seaweeds by $L$. variegatus was observed, in the following decreasing order of preference: $C$. racemosa $\approx$ Ulva $\mathrm{sp} .>O$. obtusiloba $\approx$ Sargassum sp. $>$ P. brasiliense $>D$. menstrualis. It was also verified that both methods of analysis used yielded similar results. According to the results obtained, feeding preference of $L$. variegatus is probably established by the defensive chemicals produced by $P$. brasiliense and $D$. menstrualis, and by morphological aspects of C. racemosa, Ulva sp., $O$. obtusiloba and Sargassum sp.
\end{abstract}

\section{RESUMO}

As macroalgas apresentam diversos tipos de estratégias para minimizar os danos gerados por herbívoros que influenciam a preferência alimentar dos consumidores. Este estudo avaliou a preferência alimentar do ouriço-do-mar Lytechinus variegatus em experimentos de múltipla escolha utilizando as macroalgas bentônicas Caulerpa racemosa, Dictyota menstrualis, Osmundaria obtusiloba, Plocamium brasiliense, Sargassum sp., e Ulva sp. Para verificar a importância dos aspectos morfológicos e químicos na preferência, os ensaios foram realizados com algas vivas e em pó, respectivamente. Foram utilizados dois métodos distintos de análise de dados: comparação entre a perda de biomassa e as mudanças por autogenia, e a incorporação dos valores de autogenia à perda de biomassa por herbivoria. Em ambos os experimentos observou-se uma clara preferência de $L$. variegatus por certas espécies de macroalgas em relação a outras, em ordem decrescente de preferência: C. racemosa $\approx$ Ulva $\mathrm{sp} .>O$. obtusiloba $\approx$ Sargassum $\mathrm{sp} .>P$. brasiliense $>D$. menstrualis. Além disso, constatou-se que os dois métodos de análise produziram resultados muito similares. De acordo com os resultados, a preferência alimentar de L. variegatus é provavelmente condicionada pela química defensiva produzida por $P$. brasiliense e $D$. menstrualis e aspectos morfológicos presentes em C. racemosa, Ulva sp., O. obtusiloba e Sargassum sp.

Descriptors: Lytechinus variegatus, Feeding preference, Herbivory, Seaweeds, Chemical defenses, Morphological defenses.

Descritores: Lytechinus variegatus, Preferência alimentar, Herbivoria, Macroalgas marinhas, Defesas químicas, Defesas morfológicas.

\section{INTRODUCTION}

The feeding preference of marine herbivores for seaweeds is directly related to the particular characteristics of each species (e.g. VAÏTILINGON et al., 2003; COX; MURRAY, 2006). Such characteristics can be influenced by biological processes and environmental aspects such as competition, herbivory, light intensity, temperature, salinity, water motion and nutrient availability (LOBBAN; HARRISON, 1994; DAWES, 1998). Moreover, variations in these parameters directly affect the growth and the distribution of seaweeds (LOBBAN; HARRISON, 1994; DAWES, 1998) and 
can act indirectly on their susceptibility to herbivores, modifying the amount of available nutrients and defensive chemistry (DUFFY; HAY, 1990).

Herbivory exerts an important effect on the abundance and distribution of seaweeds in diverse marine benthic communities (CARPENTER, 1986; HAY, 1997). In this way, a variety of strategies was developed by seaweeds to minimize the damages inflicted by herbivores, including chemical and structural/morphologic defenses, or occurrence in association with other unpalatable organisms (HAY; FENICAL, 1988; DUFFY; HAY, 1990). Such strategies are also important in the establishment of the feeding preferences of consumers (VAÏTILINGON et al., 2003; COX; MURRAY, 2006). In fact, understanding which factors affect the feeding preference of herbivores is fundamental to predict the effect of herbivores on seaweed communities, as well as the evolution of plant-herbivore interactions (POORE; HILL, 2006).

Seaweeds exhibit an enormous variety of sizes, forms and textures, exhibiting from delicate filaments to extensive stems, all the way to incrustating forms (LITTLER; LITTLER, 1980; LEWIS et al., 1987; HAY, 1997). However, although it is clear that some structural/morphological characteristics reduce the susceptibility of certain seaweeds to some herbivores, such correlations are many times confused due to the action of chemical defenses, calling for more studies (PAUL; HAY, 1986). Some seaweeds can modify their morphology to prevent the complete action of the herbivore. For example, Padina species (Phaeophyta) living in habitats with high herbivory pressure occur as prostrate turfs in the substratum, a morphology relatively more resistant to herbivore action (LEWIS, 1986; LEWIS et al., 1987).

In addition, seaweeds produce a great number and variety of secondary metabolites, including terpenes, aromatic compounds, acetogenins, amino acid-derived substances, and polyphenols (BLUNT et al., 2005, 2006), being mainly known for their defensive function against herbivory (HAY; FENICAL, 1988, PAUL et al., 2001). For example, Laurencia species produce more than 570 secondary metabolites, mainly halogenated compounds (BLUNT et al., 2005, 2006; FENICAL, 1975), some of them efficient against herbivory (PAUL et al., 2001).

Regular echinoids are known to be generalist herbivores feeding on marine plants and/or algae (LAWRENCE, 1975). For the majority of sea urchin species, food choice occurs in terms of their feeding preferences and of food availability (COBB; LAWRENCE, 2005). Feeding preference in tropical sea urchins is usually characterized by avoidance of certain food items that possess structural aspects and/or chemical defenses that difficult or inhibit herbivory (OGDEN, 1976; VADAS, 1977; AYLING, 1978; MCCONNELL et al., 1982; HARROLD; REED, 1985; BEDDINGFILED; McCLINTOCK, 1999; COX; MURRAY, 2006). In fact, determining an organism's food choice facilitates predictions about natural diets and food selectivity (COX; MURRAY, 2006). However, hierarchical feeding preferences established in the laboratory for benthic marine invertebrates are known for only a few species, including Strongylocentrotus spp. (VADAS, 1977), Tegula spp. (WATANABE, 1984; STEINBERG, 1985), Pachygrapsus transversus (BARRY; EHRET, 1993; PEREIRA et al., 2002), and Haliotis rubra (McSHANE et al., 1995).

Lytechinus variegatus, commonly known as the green or variegated sea urchin, is a regular urchin that inhabits the warm waters of the Western Atlantic Ocean. It inhabits waters from North Carolina and Bermuda southward to the Caribbean and Brazil (HENDLER et al., 1995). The present study had as its objective to evaluate the feeding preference of the sea urchin L. variegatus in relation to six different seaweed taxa, through multiple-choice experiments, and to determine the preponderant factors in establishing that preference.

\section{Materials And Methods \\ Collection of the Organisms}

Two seaweed species belonging to each division of macroalgae were evaluated: Plocamium brasiliense and Osmundaria obtusiloba (Rhodophyta), Dictyota menstrualis and Sargassum sp. (Phaeophyta), Ulva sp. and Caulerpa racemosa (Chlorophyta). These algae were collected at Praia Rasa (Búzios, RJ southeastern Brazil). The specimens of the sea urchin Lytechinus variegatus were collected in the sublittoral region at Itaipu Beach (Niterói, RJ - Brazil), and carried to the laboratory in containers with seawater. Specimens of L. variegatus were kept in a recirculating laboratory aquarium at constant temperature $\left(20^{\circ} \mathrm{C}\right)$, salinity (35) and aeration during the acclimation period, during which Ulva $\mathrm{sp}$. was offered as food.

\section{Morphological/structural and Chemical Characteristics} of the Seaweeds Assayed

According to the literature, the morphological/structural attributes - Table 1 (LITTLER; LITTLER, 2000) and the presence of secondary metabolites (BLUNT et al., 2005, 2006) of the seaweeds offered as food to L. variegatus differ markedly among the species assayed. 
Table 1. Characteristics of the seaweeds offered to L. variegatus in multiple-choice feeding experiments.

\begin{tabular}{lll}
\hline \hline Division & Algae & Main characteristics \\
\hline Chlorophyta & Ulva sp. & Thalli thin, sheet-like, as clusters of strap-shaped blades. \\
& Caulerpa racemosa & Frond erect possessing small, often crowded, bead-like branchlets. \\
Phaeophyta & Dictyota menstrualis & Thalli bushy, erect, and branching regularly dichotomous. \\
& Sargassum sp. & Thalli erect, tough, leathery, and sparsely branched. \\
Rhodophyta & Plocamium brasiliense & Thalli erect, and unilateral branchlets compressed to strongly flattened. \\
& Osmundaria obtusiloba & Thalli coarse, tough, bushy, and branching opposite to irregular.
\end{tabular}

Feeding Experiments

Two kinds of experiments were carried out to analyze the feeding preferences of $L$. variegatus: (1) whole seaweed species; and (2) powdered seaweeds were simultaneously made available to this sea urchin. These assays were carried out in tanks containing about $1000 \mathrm{ml}$ of seawater maintained with a continuous recirculating seawater system, constant aeration and natural photoperiod.

The first experiment encompassed a multiple-choice experiment used to evaluate the feeding preference of $L$. variegatus, in which all macroalgal species were simultaneously offered to this sea urchin. This type of assay reproduces real conditions, since in the marine environment several seaweed species are continuously exposed to consumption simultaneously. On the other hand, in this assay type it is possible to evaluate both the morphological and chemical characteristics of the species in the preference of $L$. variegatus. In this experimental series, 20 aquaria (experimental and control) were used; in each experimental aquarium, one previously weighed specimen of each macroalga (P. brasiliense, $O$. obtusiloba, D. menstrualis, Sargassum sp., Ulva sp. and C. racemosa) were placed together with 1 specimen of $L$. variegatus. The seaweeds were offered in comparable volumes to the urchin, but in different biomasses, since the volume/biomass ratio is different for each species. Simultaneously, control aquaria $(n=20)$, without herbivores, containing the weighed specimen of each algal species, were kept under the same experimental conditions, allowing measurement of biomass changes due to autogenic factors and not to herbivory (PETTERSON; RENAUD, 1989). Consumed biomass was calculated using the equation $\left[\left(\mathrm{H}_{\mathrm{o}} \times \mathrm{C}_{\mathrm{f}}\right.\right.$ $/ \mathrm{C}_{\mathrm{o}}$ )- $\mathrm{H}_{\mathrm{f}}$ ] suggested by Cronin and Hay (1996) for this type of experiment, where $\mathrm{H}_{\mathrm{o}}$ and $\mathrm{H}_{\mathrm{f}}$ correspond to the initial and final wet masses, respectively, and $\mathrm{C}_{\mathrm{o}}$ and
$\mathrm{C}_{\mathrm{f}}$ to the initial and final control masses. In another method, consumption and autogenic values were compared statistically ( $t$ test) to verify the existence of significant differences or the existence of consumption. Eight and $32 \mathrm{~h}$ after the beginning of the experiment, seaweeds were reweighed to determine loss of biomass due to herbivory. All weights were obtained from wet material from which excess of water was removed using a "salad spinner".

In the second experiment, a multiple-choice experiment was also used, this time to evaluate the feeding preference of $L$. variegatus related to the chemical aspect, since feeding preferences were evaluated using artificial food wafers (described in Hay et al., 1994) prepared with the powdered algae. Artificial food wafers were prepared by adding $0.72 \mathrm{~g}$ of agar to $20.0 \mathrm{ml}$ of distilled water and heated to a boil in a microwave oven. This mixture was then added to $16.0 \mathrm{ml}$ of distilled water containing $2.0 \mathrm{~g}$ of each freeze-dried macroalga. The mixture of each species was hardened onto a mesh screen and cut into small pieces $(10.0 \times 10.0$ squares each ca. $1.0 \mathrm{~mm}$ on a side), which were then offered to the sea urchin simultaneously and equidistantly in the containers (n $=15$ ). Feeding preference was estimated by comparing the percentage of squares of treated and control food wafers consumed

\section{Statistical Treatment}

Normality of the data was evaluated through the Kolmogorov-Smirnov and Shapiro-Wilk tests, and later adjusted by statistical tests (ZAR, 1996). Data treatment was descriptive, since multiple-choice experiments are still the target of much discussion in the literature (PETERSON; RENAUD, 1989; ROA, 1992; LOCKWOOD, 1998; RAFFA et al., 2002; PRINCE et al., 2004). Data from experimental and autogenic controls were compared by $t$ test analysis. 


\section{Results}

Experiment with whole Seaweeds

In the first assays using whole seaweeds, and in which autogenic values were incorporated into corresponding variation in biomass due to herbivory, $L$. variegatus exhibited a clear and consistent preference, independently of period of the experiment. In the first $8 \mathrm{~h}$ after experiment start, this sea urchin established a hierarchy among algal species, in decreasing sequence of preference (Fig. 1): $C$. racemosa $>$ Ulva $\mathrm{sp.}>$ Sargassum $\mathrm{sp} .>$ O. obtusiloba $>P$. brasiliense $>D$. menstrualis. Higher percent masses of these seaweeds were eaten by $L$. variegatus after $32 \mathrm{~h}$ of experiment, but the same hierarchy was maintained among the species (Fig. 1). Based on these results, it can be said that $L$. variegatus strongly discriminates among seaweed species, eating preferentially the green species C. racemosa and Ulva sp. over the four other seaweeds.

These results, when analyzed by comparison between biomass loss due to herbivory and that due to autogenic variation, revealed a very similar decreasing preference sequence by $L$. variegatus. The pattern of C. racemosa and Ulva sp. as preferred food items, Sargassum sp. and $O$. obtusiloba in intermediary preference, and $P$. brasiliense and $D$. menstrualis as less preferred items was observed in both periods, $8 \mathrm{~h}$ and $32 \mathrm{~h}$ after beginning the experiment (Figs 2 and 3, respectively).

Comparison between the two methods of data analysis yielded very similar results, both in relation to consumption detected, as well as in the order of preference of seaweeds.

\section{Experiment with Powdered Seaweeds}

In the second experiment, involving feeding preference of $L$. variegatus for artificial food containing seaweeds, the following decreasing sequence of preference was observed: Ulva sp. $>C$. racemosa $>O$. obtusiloba $>$ Sargassum sp. $>P$. brasiliense $>D$. menstrualis (Fig. 4); in fact, a very similar sequence was also observed in the first assay using whole seaweeds.

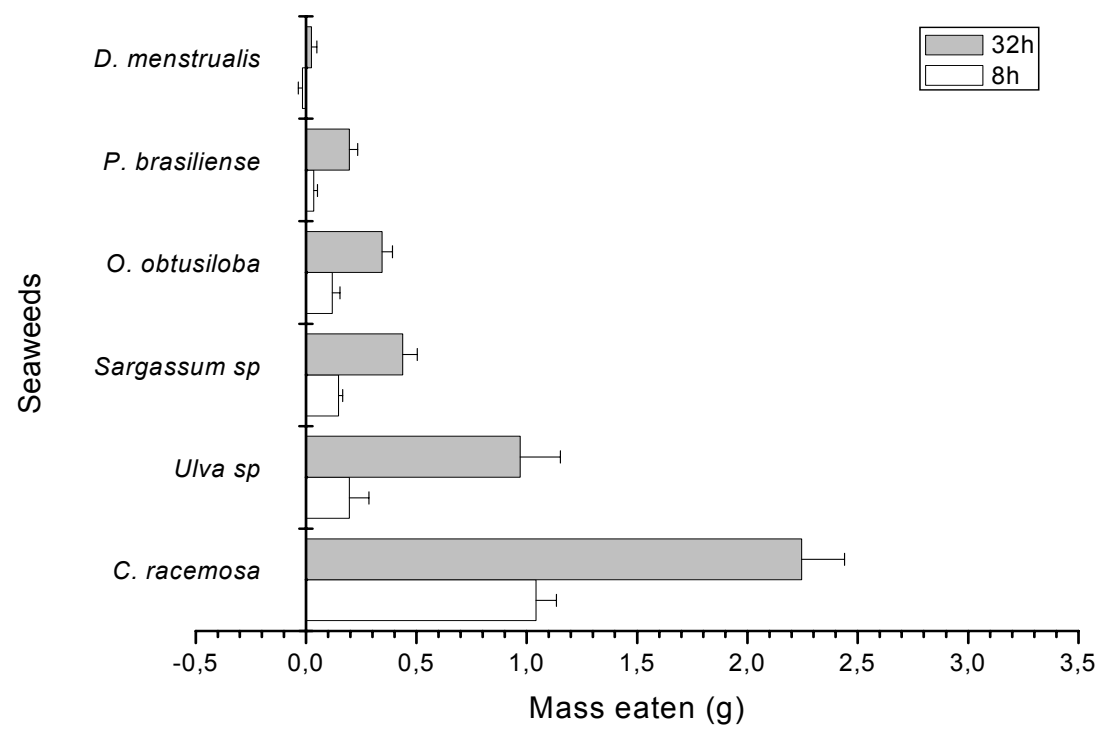

Fig. 2. Consumption ( $\mathrm{g})$ of the seaweeds by L. variegatus after $8 \mathrm{~h}$ and $32 \mathrm{~h}$ of experiment $(\mathrm{n}=$ 20). Horizontal bars at each point represent mean and standard deviations. 


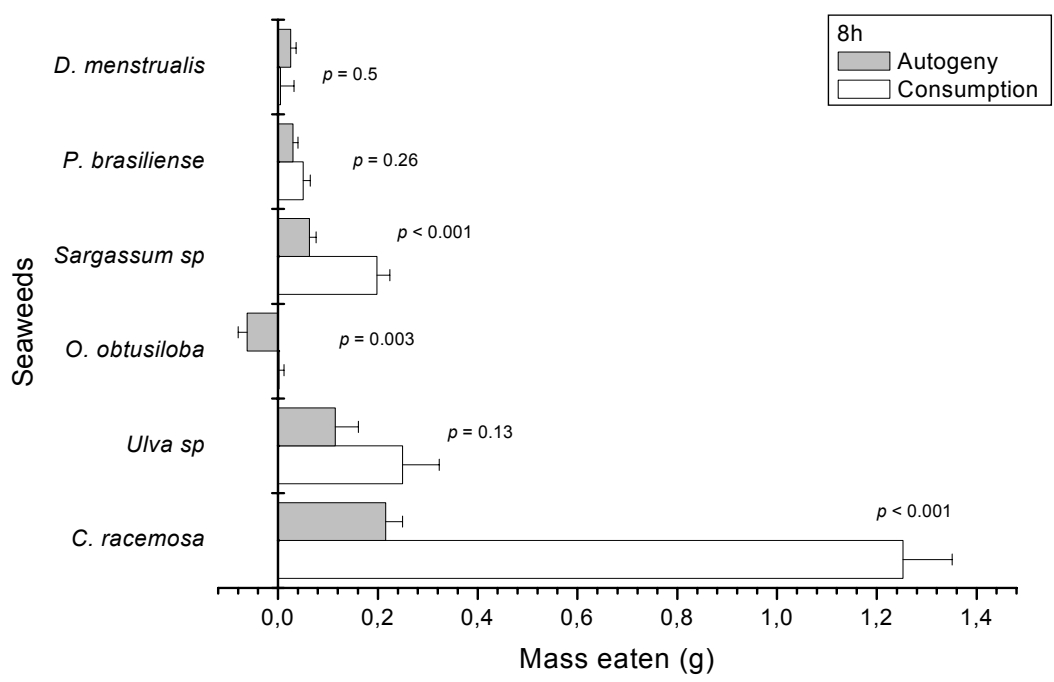

Fig. 2. Consumption ( $\mathrm{g}$ ) of the seaweeds by $L$. variegatus after $8 \mathrm{~h}$ of experiment $(\mathrm{n}=20)$. The losses of biomass due to herbivory and autogenic changes are compared $(t$ test, $\alpha=0.05)$. Horizontal bars at each point represent mean and standard deviations.

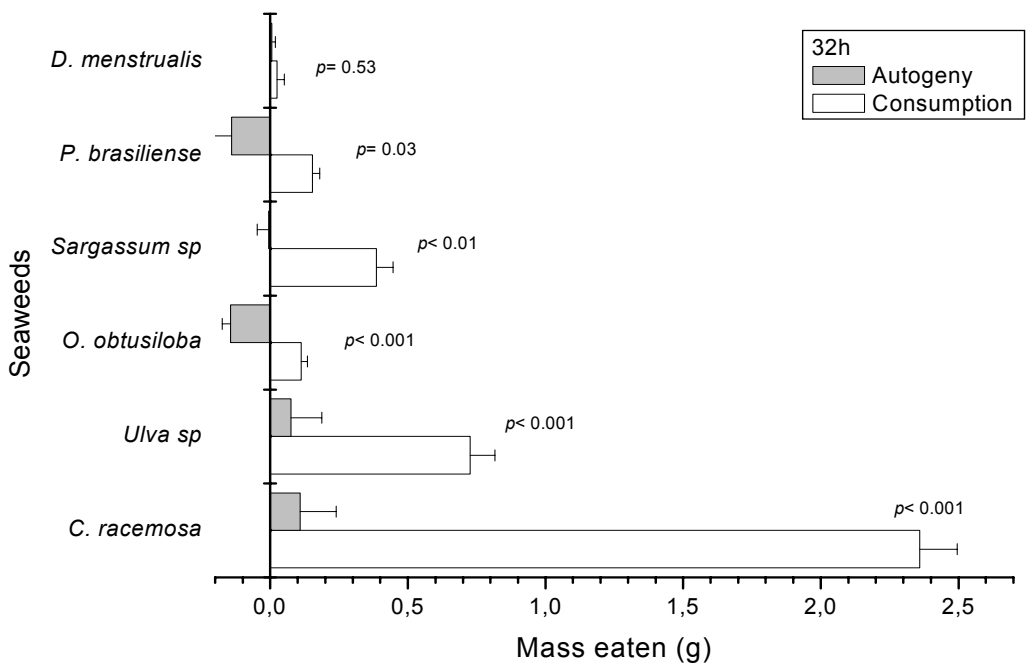

Fig. 3. Consumption ( $\mathrm{g}$ ) of the seaweeds by L. variegatus after $32 \mathrm{~h}$ of experiment $(\mathrm{n}=20)$. Biomass losses due to herbivory and autogenic changes are compared $(t$ test, $\alpha=0.05)$. Horizontal bars at each point represent mean and standard deviations. 


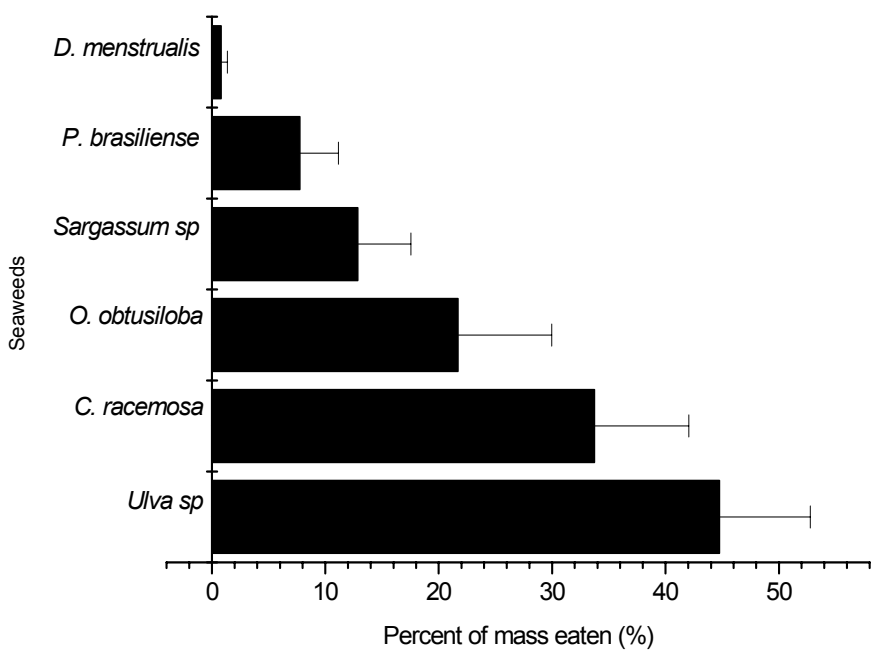

Fig. 4. Percent of mass eaten (\%) by L. variegatus during the experiment with powdered seaweeds. Horizontal bars at each point represent mean and standard deviations.

\section{Discussion}

The sea urchin L. variegatus is a generalist grazer of algae (LOWE; LAWRENCE, 1976; VADAS et al., 1982; GREENWAY, 1995; BEDDINGFIELD; MCCLINTOCK, 1999), and occasionally of animals (LOWE; LAWRENCE, 1976). For example, in central Florida this urchin can primarily consume macroflora, except in periods when abundance of algae is extremely limited (COBB; LAWRENCE, 2005). In both experiments (live and powdered seaweeds) the sea urchin $L$. variegatus presents a clear feeding preference for certain seaweed species over others. Of the seaweeds used in this study, the decreasing order of preference was: C. racemosa $\approx$ Ulva sp. $>O$. obtusiloba $\approx$ Sargassum sp. $>$ P. brasiliense $>D$. menstrualis. This pattern was similar 8 and $32 \mathrm{~h}$ after the beginning of the experiment, showing that it is this urchin's preferential consumption of the six different seaweed species. This verified feeding preference of $L$. variegatus can be attributed to structural features, as well as to the supposed presence of secondary metabolites.

In the morphological context, the results obtained correspond partially to the proposal by Littler et al. (1983) to classify seaweeds according to their morphological aspects related to resistance against herbivores, where species can be placed in the following decreasing order of resistance: crustose $>$ jointed calcareous $>$ thick leathery $>$ coarsely branched $>$ sheet $>$ filamentous. This classification would explain the higher preference of $L$. variegatus for sheet (Ulva sp.), coarsely branched (C. racemosa), and thick leathery (Sargassum sp. and O. obtusiloba) species of seaweeds.

However, according to Littler et al. (1983), the sheet texture of $D$. menstrualis would result in a high consumption rate for the species, which was not observed in our experiments. In fact, the morphology of $D$. menstrualis does not represent the preponderant aspect in this preference. In like manner, although $P$. brasiliense possesses a thick coarsely branched aspect, it was not highly consumed. This contributes to indicate that other aspects are probably related in this question. In fact, seaweed morphology is not the only reason for sea urchin preferential feeding. Wessels et al. (2006) demonstrated that physical structure, i.e., both rigidity and resistance, seems to be sufficiently effective against consumption by amphipods, but has little effectiveness against sea urchins.

$$
\text { In the assays using powdered seaweed }
$$
incorporated into artificial foods, morphologic/structural characteristics were removed, but these aspects had little relevance in the choices of L. variegatus, since preference order showed little difference from the experiment with live seaweed. In this in case, the chemical aspects (defensive and nutritional) preserved in powdered specimens reinforce the hypothesis that the feeding preference of $L$. variegatus is mediated by seaweed chemicals.

Among brown seaweeds, those belonging to genus Dictyota are known to produce secondary 
lipophilic metabolites that can act as defensive chemicals (PAUL et al., 2001), including D. menstrualis from Brazil that produces chemical defenses against herbivores (e.g. PEREIRA et al., 2000). It is thus not unwarranted to affirm that the low preference of $L$. variegatus for Dictyota menstrualis is related to chemical defenses.

Diverse species of genus Plocamium are also known to produce halogenated secondary metabolites (see Blunt et al., 2005, 2006 for reviews) which confer to them low susceptibility to herbivory (ARGANDOÑA et al., 2002; AMSLER et al., 2005; HUANG et al., 2006), including $P$. brasiliense from the Brazilian coast (PEREIRA et al., 2002). Therefore, the low preference or the reduced consumption of $P$. brasiliense by $L$. variegatus may be due to the presence of chemical defenses in this red seaweed.

Diverse species of Chlorophyta, including those belonging to genera Caulerpa and Ulva, also produce secondary metabolites that inhibit herbivory (PAUL et al., 2001; VAN ALSTYNE; HOUSER, 2003). In C. racemosa it was observed that, although it produces high concentrations of sesquiterpenes ( 1 to $2 \%$ of dry weight), this seaweed is easily consumed by fish (PAUL; HAY, 1986; MEYER; PAUL, 1992). Also, the major metabolite caulerpenine does not inhibit most fishes (WYLIE; PAUL, 1988; MEYER; PAUL, 1992), although it is able to influence other herbivores, such as some gastropods (PAUL; FENICAL, 1986). In the present study, it was observed that $C$. racemosa was consumed in high amounts both with alive and triturated specimens. Thus, we verify that the morphologic and chemical defenses of $C$. racemosa are not efficient agaisnt $L$. variegatus.

During the experiment with live seaweeds it was observed that the individuals of $L$. variegatus, when manipulating $C$. racemosa, gave clear priority to consumption of the erect portions of the thallus, leaving the stolon to consume later, a fact also observed in another green seaweed, Neomeris anulata (LUMBANG; PAUL, 1996). This fact can be related to the distinguishing allocation of chemical defenses. According to Optimal Defense Theory (ODT), parts and structures that are more valuable for the organism, or those that are more vulnerable to attack, have high levels of defensive resources (CRONIN, 2001). In this way, it is possible to suppose that the erect parts of $C$. racemosa are more susceptible to consumption due to differential distribution of chemicals, rather than to the absence of defense.

In general, Ulva species are more preferred by herbivores and are usually included in artificial foods used in chemical ecology studies (HAY; STEINBERG, 1992). However, some Ulva species also produce chemically activated defense against herbivores (VAN ALSTYNE; HOUSER, 2003).
Usually, they are difficult to distinguish, and we were unable to identify the species used here, but it probably does not produce defensive chemicals, since it was used in previous studies as the major component of artificial foods (PEREIRA et al., 2000), or was preferentially consumed in feeding preference assays (PEREIRA et al., 2002).

According to Cobb and Lawrence (2005), specimens of $L$. variegatus are clearly omnivorous but exhibit a stronger preference for algal and plant material than for animals. Our observations indicate that the feeding preference of $L$. variegatus is probably due either to chemical or morphological defenses produced by the seaweeds tested.

\section{AcKNowledgements}

This work was supported by the Conselho Nacional de Desenvolvimento Científico e Tecnológico (CNPq) and Fundação de Amparo à Pesquisa do Estado do Rio de Janeiro (FAPERJ), through research grants.

\section{REFERENCES}

AMSLER, C. D.; IKEN, K.; MCCLINTOCK, J. B.; AMSLER, M. O.; PETERS, K. J.; HUBBARD, J. M.; FURROW, F. B.; BAKER, B. J. Comprehensive evaluation of the palatability and chemical defenses of subtidal macroalgae from the Antarctic Peninsula. Mar. Ecol. Prog. Ser., v. 294, p. 141-159, 2005.

ARGANDOÑA, V. H.; ROVIROSA, J.; SAN-MARTÍN, A.; RIQUELME, A.; DÍAZ-MARRERO, A. R.; CUETO, M.; DARIAS, J.; SANTANA, O.; GUADAÑO, A.; GONZÁLEZ-COLOMA, A. Antifeedant effects of marine halogenated monoterpenes. J. Agric. Food Chem., v. 50, p.7029-7033, 2002.

AYLING, A. L. The relation of food availability and food preferences to the field diet of an echinoid Evechinus chloroticus (Valenciennes). J. Exp. Mar. Biol. Ecol., v. 33, p. 223-235, 1978.

BARRY, J. P.; EHRET, M. J. Diet, food preference, algal availability for fishes and crabs on intertidal reef communities in southern California. Environ. Biol. Fishes, v. 37, p. 75-95, 1993.

BEDDINGFIELD, S. D.; MCCLINTOCK, J. B. Food resource utilization in the sea urchin Lytechinus variegatus in contrasting shallow-water microhabitats of Saint Joseph Bay, Florida. Gulf Mex. Sci., v. 1, p. 27-34, 1999.

BLUNT, J. W.; COOP, B. R.; MUNRO, M. H. G.; NORTHCOTE, P. T.; PRINSEP, M. R. Marine natural products. Nat. Prod. Rep., v. 22:15-61, 2005.

BLUNT, J. W.; COOP, B. R.; MUNRO, M. H. G.; NORTHCOTE, P. T. Marine natural products. Nat. Prod. Rep., v. 23, p. 26-78, 2006.

CARPENTER, R. C. Partitioning herbivory and its effects on coral reef algal communities. Ecol. Monogr., v. 56, p. 345-363, 1986. 
COX, E. T.; MURRAY, N. S. Feeding preferences and the relationships between food choice and assimilation efficiency in the herbivorous marine snail Lithopoma undosum (Turbinidae). Mar. Biol., v. 148, p. 1295-1306, 2006.

COBB, J.; LAWRENCE, J. M. Diets and coexistence of the sea urchins Lytechinus variegatus and Arbacia punctulata (Echinodermata) along the central Florida Gulf coast. Mar. Ecol. Prog. Ser., v. 295, p. 171-182, 2005.

CRONIN, G. Resource allocation in seaweeds and marine invertebrates: chemical defense patterns in relation to defense theories. In: MCCLINTOCK J. B.; BAKER B. J. (Ed.). Marine chemical ecology. Boca Raton: CRC Press, 2001. p. 325-353.

CRONIN, G.; HAY, M.E. Susceptibility to herbivores depends on recent history of both the plant and animal. Ecology, v. 77, p. 1531-1543, 1996.

DAWES, C. J. Marine Botany. $2^{\text {nd }}$ ed. New York: John Wiley \& Sons, 1998. $490 \mathrm{p}$

DUFFY, J. E. \& HAY, M. E. Seaweed adaptations to herbivory. Bioscience, v. 40, p. 368-374, 1990.

FENICAL, W. Halogenation in rhodophyta - review. J. Phycol., v. 11, p. 245-259, 1975.

GREENWAY, M. Trophic relationships of macrofauna within a Jamaican seagrass meadow and the role of the echinoid Lytechinus variegatus (Lamarck). Bull. mar. Sci., v. 56, p. 719-736, 1995.

HARROLD, C.; REED, D. C. Food availability, sea urchin grazing, and kelp forest community structure. Ecology, v. $66: 116-169,1985$

HAY, M. E. The ecology and evolution of seaweedherbivore interactions on coral reefs. Coral Reefs, v. 16 , p. 67-76, 1997.

HAY, M. E.; FENICAL, W. Marine plant-herbivore interactions: The ecology of chemical defenses. Ann. Rev. Ecol. Syst., v. 19, p. 111-145, 1988.

HAY, M. E.; STEINBERG, P. D. The chemical ecology of plant herbivore interactions in marine versus terrestrial communities. In: ROSENTHAL, G. A.; BERENBAUM, M. R. (Ed.). Herbivores - their interactions with secondary plant metabolites. New York: Academic Press, 1992. p.371-413.

HAY, M. E.; KAPPEL, Q. E.; FENICAL, W. Synergisms in plant defenses against herbivores: interactions of chemistry, calcification and plant quality. Ecology, v. 75 p. 1714-1726, 1994

HENDLER, G.; MILLER, J. E.; PAWSON, D. L.; KIER, P. M. 1995. Sea stars, sea urchins, and allies. Washington DC: Smithsonian Institution Press, 1995. 392 p.

HUANG, Y. M., MCCLINTOCK, J. B., AMSLER, C. D., PETERS, K. J.; BAKER, B. J. Feeding rates of common Antarctic gammarid amphipods on ecologically important sympatric macroalgae. J. Exp. Mar. Biol. Ecol., v. 329, p. 55-65, 2006

LAWRENCE, J. M. On the relationship between marine plants and sea urchins. Oceanogr. Mar. Biol. Ann. Rev., v. $132,135-286,1975$.

LEWIS, S. M. 1986. The role of herbivorous fishes in the organization of a Caribbean reef community. Ecol. Monogr., v. 56, p. 83-200, 1986

LEWIS, S. M.; NORRIS, J. N.; SEARLES, R. B. The regulation of morphological plasticity in tropical reef algae by herbivory. Ecology, v. 68, p. 636-641, 1987.
LITTLER, M. M.; LITTLER, D. S. The evolution of thallus form and survival strategies in benthic marine macroalgae: field and laboratory tests of a functional form model. Am. Naturalist., v. 116, p. 25-44, 1980.

LiTTLER, M. M.; LITTLER, D. S.; TAYLOR, P. R. Evolutionary strategies in a tropical barrier reef system: functional-form groups of marine macroalgae. J. Phycol., v. 19, p. 229-237, 1983.

LITTLER, D. S.; LITTLER, M. M. An identification guide to the reef plants of the Caribbean, Bahamas, Florida and Gulf of Mexico. $1^{\text {st }}$. ed. Washington,Off Shore Graphic, 2000. 542 p.

LOBBAN, C. S.; HARRISON, P. J. Seaweed ecology and physiology. $1^{\text {st }}$. ed. Cambridge: Cambridge University Press., 1994. p.366.

LOCKWOOD, J. R. On the statistical analysis of multiplechoice feeding preference experiments. Oecologia, v. 116, p. 475-481, 1998.

LOWE, E. F.; LAWRENCE, J. M. Absorption efficiencies of Lytechinus variegatus (Lamarck) (Echinodermata: Echinoidea) for selected marine plants. J. Exp. Mar. Biol. Ecol., v. 21, p. 223-234, 1976.

LUMBANG, W. A.; PAUL, V. J. Chemical defenses of the tropical green seaweed Neomeris annulata Dickie: Effects of multiple compounds on feeding by herbivores. J. Exp. Mar. Biol. Ecol., v. 201, p. 185-195, 1996.

MCCONNELL, O.; HUGHES, P. A.; TARGETT, N. M.; DALEY, J. Effects of secondary metabolites from marine algae on feeding by the sea urchin, Lytechinus variegatus. J. Chem. Ecol., v. 8, p. 1437-1453, 1982.

MCSHANE, P. E., GORFINE, H. K; KNUCKEY, I. A. Factors influencing food selection in the abalone Haliotis rubra (Mollusca: Gastropoda). J. Exp. Mar. Biol. Ecol., v. 176, p. 27-37, 1995.

MEYER, K. D.; PAUL, V. J. Intraplant variation in secondary metabolite concentration in three species of Caulerpa (Chlorophyta: Caulerpales) and its effects on herbivorous fishes. Mar. Ecol. Prog. Ser., v. 82, 249257, 1992.

OGDEN, J.C. Some aspectes of herbivore-plant relationships on Caribbean reefs and seagrass beds. Aq. Bot., v. 2, . 103-116, 1976.

PAUL, VJ; FENICAL, W. Chemical defense in tropical green-algae, order Caulerpales. Mar. Ecol. Prog. Ser., v. 34, p. 157-169. 1986.

PAUL, V. J.; HAY, M. E. Seaweed susceptibility to herbivory - chemical and morphological correlates. Mar. Ecol. Prog. Ser., v. 33, p. 255-264, 1986.

PAUL, V. J.; CRUZ-RIVERA, E.; THACKER, R. W. Chemical mediation of macroalgal-herbivore interactions: ecological and evolutionary perspectives. In: MCCLINTOCK, J. B.; BAKER, B. J. (Ed.). Marine chemical ecology. Boca Raton: CRC Press, 2001. p. 227-265.

PEREIRA, R. C.; CAVALCANTI, D. N.; TEIXEIRA, V. L. Effects of secondary metabolites from the tropical Brazilian brown alga Dictyota menstrualis on the amphipod Parhyale hawaiensis. Mar. Ecol. Prog. Ser., v. 205 , p. $95-100,2000$.

PEREIRA, R. C.; PINHEIRO, M. D., TEIXEIRA, V. L.; GAMA, B. A. P. Feeding preferences of the endemic gastropod Astraea latispina in relation to chemical defenses of Brazilian tropical seaweeds. Braz. J. Biol., v. 62 , p. $33-40,2002$. 
PETERSON, C. H.; RENAUD, P. E. Analysis of feeding preference experiments. Oecologia,v. 80, p. 82-86, 1989.

POOR, G. H.; HILL, N. A. Sources of variation in herbivore preference: among-individual and past diet effects on amphipod host choice. Mar. Biol., v. 149, p. 1403-1410, 2006.

PRINCE, J. S.; LEBLANC, W. G.; MACIÁ, S. Design and analysis of multiple choice feeding preference data. Oecologia, v. 138, p. 1-4, 2004.

RAFFA, K. F.; HAVILL, N. P.; NORDHEIM, E. V. How many choices can your test animal compare effectively? Evaluating a critical assumption of behavioral preference tests. Oecologia, v. 133, p. 422-429, 2002.

ROA, R. Design and analysis of multiple-choice feedingpreference experiments. Oecologia, v. 89 , p. 509-515, 1992.

STEINBERG, P. D. Feeding preferences of Tegula funebralis and chemical defenses of marine brown algae. Ecol. Monogr., v. 55, p. 333-349, 1985.

VADAS, R. L. Preferential feeding: An optimization strategy in sea urchins. Ecol. Monogr., v. 47, p. 337-371, 1977.

VADAS, R. L.; FENCHEL, T.; OGDEN, J. C. Ecological studies on the sea urchin, Lytechinus variegatus, and the algal-seagrass communities of the Miskito Cays, Nicaragua. Aq. Bot., v. 14, p. 109-125, 1982.

VAITILINGON, D., MORGAN, R., GROSJEAN, PH., GOSSELIN, P.; JANGOUX, M. Effects of delayed metamorphosis and food rations on the perimetamorphic events in the echinoid Paracentrotus lividus (Lamarck, 1816) (Echinodermata). J. Exp. Mar. Biol. Ecol., v. 262, n. 1, p. 41-60, 2003.
VAN ALSTYNE, K. L.; HOUSER, L. T. 2003. Dimethylsulfide release during macroinvertebrate grazing and its role as an activated chemical defense. Mar. Ecol. Prog. Ser., v. 250, p. 175-181, 2003.

WATANABE, J. M. Food preference, food quality and diets of three herbivorous gastropods (Trochidae: Tegula) in a temperate kelp forest habitat. Oecologia, v. 62, p. 47-52, 1984.

WESSELS, H.; HAGEN, W.; MOLIS, M.; WIENCKE, C.; KARSTEN, U. Intra- and interspecific differences in palatability of Arctic macroalgae from Kongsfjorden (Spitsbergen) for two benthic sympatric invertebrates. J. Exp. Mar. Biol. Ecol., v. 329, p. 20-33, 2006.

WYLIE, C. R.; PAUL V. J. Feeding preferences of the surgeonfish Zebrasoma flavescens in relation to chemical defenses of tropical algae. Mar. Ecol. Prog. Ser., v. 45:23-32, 1988

ZAR, J. H. Biostatistical analysis. $3^{\text {rd }}$. ed.. Upper Saddle River, N.J.: Prentice Hall, 1996. 920 p.

(Manuscript received 31 August 2007; revised 27 September 2007; accepted 12 November 2007) 